\title{
Motivation to Learn English and School Grade Level: The Case of Newly Arrived Hong Kong Students
}

\author{
Ruth M. H. WONG \\ The Hong Kong Institute of Education
}

Received: 28 July 2012 / Accepted: 29 May 2013

ISSN: $1697-7467$

\begin{abstract}
Numerous studies have investigated how motivation relates to various individual differences. However, research did not uncover any previous studies investigating how school grade level impacts second language learning motivation. This study therefore focuses on how different school forms are related to motivation to learn English - this subject is particularly important in the Hong Kong school context because the English proficiency of Newly Arrived Hong Kong (NAHK) students is assessed once they arrive Hong Kong and the results will determine which school grade level they will attend. It is hoped that this investigation into the relationship between school forms and motivation for this group will have implications for improvements in current teaching and learning practices, based on the adopted motivational theory. It is further hoped that the results will enhance NAHK student motivation to learn English even as they adjust to and integrate with their new learning environment. This study adopted both qualitative and quantitative approach of investigation. The questionnaire included items on different motivational constructs at different levels, based on the conceptual framework of Dornyei (1998). To clarify any gaps in data appearing after analysis of the statistical results, interviews were conducted with 10 randomly chosen respondents. This study established that Hong Kong upper secondary school students overall have stronger motivation, very likely because of their need for further studies and career aspirations.
\end{abstract}

Keywords: Motivation to learn, English, Newly Arrived Hong Kong students.

Motivación para aprender Inglés y el Sistema de Grados en Escuelas: El caso de estudiantes recién llegados a Hong Kong

RESUMEN: Numerosos estudios han investigado cómo la motivación se relaciona con distintas diferencias entre personas individuales. Sin embargo, ningún estudio previo ha investigado cómo el sistema de grados en escuelas influye en la motivación del aprendizaje de una segunda lengua. Por lo tanto, este estudio se enfoca en cómo diferentes grados en las escuelas están relacionadas con la motivación de aprender inglés, siendo este tema particularmente importante en el contexto de las escuelas en Hong Kong debido a que el dominio del Inglés de Personas Recién Llegadas a Hong Kong (NAHK) es evaluado una vez que ellos llegan a Hong Kong y estos resultados determinan a qué nivel de Primaria tendrán que integrarse de estos estudiantes. Se espera que este estudio sobre la relación entre del grado en las escuelas y la motivación de este grupo tenga implicaciones para el mejoramiento de las prácticas actuales de enseñaza y aprendizaje, basados en la teoría de motivación adoptada. Además, se espera que los resultados mejoren la motivación de estudiantes NAHK para aprender inglés, incluso mientras se adaptan e integran a su nuevo entorno de aprendizaje. En 


\begin{abstract}
este estudio se adopta investigación cuantitativa tanto como cualitativa. El cuestionario incluye datos sobre los diferentes constructos motivacionales en diferentes niveles, basados en el sistema conceptual de Dornyei (1998). Para aclarar las posibles brechas en los datos que aparecen después del análisis de los resultados estadísticos, se realizaron entrevistas con 10 encuestados elegidos al azar. Este estudio estableció que los alumnos de escuelas de segundo ciclo secundario en Hong Kong tienen mayor motivación en general, muy probablemente debido a su necesidad de continuar estudios y aspiraciones profesionales.

Palabras clave: Motivación para aprender, Inglés, Personas Recién Llegadas a Hong Kong.
\end{abstract}

\title{
1. INTRODUCTION
}

Numerous studies have been conducted to investigate student motivation; however, no research has examined how school form attended is related to the second language learning pattern of Chinese immigrant students. This study, therefore undertakes this challenge, specifically studying Newly Arrived Hong Kong (NAHK) students. The understanding gained could have positive implications for current teaching and learning practices, based on the adopted motivational theory. Furthermore, students' motivation to learn English may be enhanced, thus enabling them to better integrate into their new learning environment, eventually improve their careers, and ultimately contribute more to Hong Kong society.

In many countries, the relationship between age and school form attended are considered a single demographic characteristic because they are essentially fixed; hence they are combined for analysis in studies seeking relationships within learning motivation (see Corpus \& Lepper, 2007 \& Fomer, Cole, Sigal, Benbow, Satterwhite, Swygert \& Ciesla, 2008). However, the case of NAHK students is different. It begins upon arrival in Hong Kong when they are given Chinese and English proficiency tests to assess whether they need special language support. Consequently, many NAHK students repeat one or more academic years to reach the English standard required by Hong Kong curriculum. In fact, due to their poorer English standard, many students are recommended to attend a form three years lower than their Mainland form. For example, two sisters, aged 16 and 18 years, and one brother aged 15, came to Hong Kong together. Eventually, the two sisters studied in the same Form 5 class (Grade 11) and the brother studied in Form 1 (Grade 7). In other words, age and school form are not necessarily 'locked-in' to one another for NAHK students. They are not two sides of the same coin. Therefore age and school form must be regarded as two independent demographic characteristics.

\section{Conceptual framework}

Motivation has long been a hot topic in educational research because of its complexity. The construct of motivation is not a single entity but a multi-factorial one. Factors like socio-psychology, cognitive development, and socio-cultural psychology all have impact on motivation in language learning. Dörnyei's work has been considered as one of the most 
influential contemporary motivational constructs in L2 (see Table 1). Dörnyei (1998) reviewed over 80 relevant L2 studies and combined most of the major motivational theories and constructs into his motivation framework (Wong, 2007a). Dörnyei's model fills the gaps of Oxford and Shearin's (1994) and Williams and Burden's (1997) work. However, there are two important criteria have not yet been fulfilled-(1) the role of parents played in students' L2 learning motivation has been ignored (Wong, 2007a) and (2) the role culture played in influencing L2 learning motivation.

When examining Dörnyei's model, it is believed that parent-specific component under learning situation level has also to be integrated with Dörnyei's current model (Wong, 2007d). Researches also indicated that family involvement improves facets of children's education such as motivation (Cheung \& Pomerantz, 2012; Froiland, 2011; Ghazi, Ali, Shahzad \& Khan, 2010; Gutman \& Midgley, 2000; Huang \& Mason, 2008; Shumow \& Miller, 2001; Usher \& Kober, 2012). Interestingly, Dörnyei and Schmidt (2001) also noted parental influence plays a large part in students' learning motivation in his own work although he does not include it as a component in his framework.

Clark (cited in Wlodkoswki \& Jayne, 1990), who spent more than a decade studying well-motivated high achievers at both the secondary school and primary school levels, found that what makes the difference for highly motivated student is that they come from "effective family". He termed effective family as one with several characteristics, "family income, education and ethnic background." Based on this, the component of parent-specific motivation added to Dörnyei's model can be broken down into further constituents (Wong, 2007b):

- Education background

- Financial support

- Affective encouragement

Apart from parents, culture also plays an important role in determining how students perceive their own identity in an environment which leads to their language learning strategies and very often, they are the factors which determine the success of language learning. For example, one can see many researches in fact identify the roles of social integration and cultural differences in acquiring a second language (Chiu \& Chow, 2010; Lin, 2010; Maehr, 2008; Szeto, Sorrentino, Yasunaga, Kouhara, Stephens, Romakin, Yukhymenko, 2010; Trumbull \& Rothstein-Fisch, 2011). Differences in cultural values, beliefs (Becker et al, 2012; Hess \& Azuma, 1991; Holloway \& Hess, 1990), and practices (Stevenson \& Stigler, 1992; Thijs, 2012) have been the foci of many studies. These cultural values and practices are assumed to influence student motivation and subsequent achievement. It is therefore important to consider culture as one of the determining factors and see how culture affects a particular group of learners' motivation to learn English.

Table 1 shows culture-specific and parent-specific motivational component added to Dörnyei's conceptual framework which is to be used as the conceptual framework of this study. 
Table 1. Culture-specific and parent-specific motivational component added to Dörnyei's conceptual framework

Language Level
Learner Level
Learning Situation Leve
Course-specific
Motivation Components

Teacher-Specific

Motivational components

Group-Specific

Motivational Components

*Parent-Specific Motivation

Components

*Culture-Specific Motivation

Component
Integrative motivational subsystem

Instrumental motivational subsystem

Need for achievement

Self-confidence

* Language use anxiety

*Perceived L2 Competence

*Casual attributions

*Self-efficacy

Interest (in the course)

Relevance (of the course to one's needs)

Expectancy (of success)

Satisfaction (one has in the outcome)

Affiliative motive (to please the teacher)

Authority type (autonomy-supporting)

Direct Socialization of Motivation

*Modeling

*Task Presentation

*Feedback

Goal-orientations

Norm \& Reward System

Group Cohesion

Classroom Goal Structure

Education background-English proficiency level

Financial support

Affective encouragement

Socio-cultural integration

* New motivation component added to Dörnyei’s (1998) extended framework.

\section{Methodology}

\subsection{Design of Research Methods}

The questionnaire included items on different motivational constructs at different levels, based on the conceptual framework mentioned previously. They were language level, learner level and learning situation level. Three statements were constructed for each sub-component 
under each motivation dimension. Items on parental education background and family income were also included in the questionnaire. The questionnaires administered to students were in Chinese, their native language, in order to avoid the problems with language barrier and communication breakdown.

To clarify any gaps in data appearing after preliminary analysis of the statistical results, interviews were conducted in both face-to-face and semi-structured styles with 10 randomly chosen respondents.

\subsection{Participants}

Of the 109 NAHK secondary school students who accepted the invitation to join this study, 53 were girls and 56 were boys. All were aged 13-19 and had lived in Hong Kong for less than three years.

\subsection{Procedures}

A pilot study was conducted in Chinese before the final questionnaire was set, and students were invited to comment on its language and content. Questionnaire items were also subjected to a reliability test. Several items were amended due to lack of clarity, while the reliability test found certain question items not statistically trustworthy.

For the main study, all students were gathered in the school hall and were given thirty minutes to complete the approved questionnaire under the researcher's supervision and direction. Students were also assured that their information would only be used for the purposes of this study. Respondents were reminded that their participation was completely voluntary and that all data collected would remain confidential. Informed consent forms were also distributed. Statistical analyses were carried out using Statistical Package for the Social Sciences (SPSS).

\subsection{Data Analysis}

Data collected from the questionnaire was analysed using SPSS. Descriptive analyses (means and standard deviations) were mainly used to project participants' motivation and learning strategies for English study.

\subsection{Research Questions}

This study set the following research questions for testing:

1. Do NAHK students gain more motivation to learn English as they advance into higher school grade level?

2. How exactly do different school grade levels affect the motivation of NAHK students to learn English at the different motivational dimensions (i.e., language level, leaner level and learning situation level)?

3. How do different school grade levels affect the motivation of NAHK students to learn English under different motivational components (i.e., course-, teacher-, group-, parent- and culture-specific motivational components)? 


\section{Findings}

Using mean scores by form, Table 2 shows there is no sign of improvement in NAHK students' motivation to learn English as they advance. However, the means of Table 2 do reveal one other fact - NAHK students in Form 5 are the group with the strongest motivation and/or ability to learn of all students (M: 4.623, SD: 0.317).

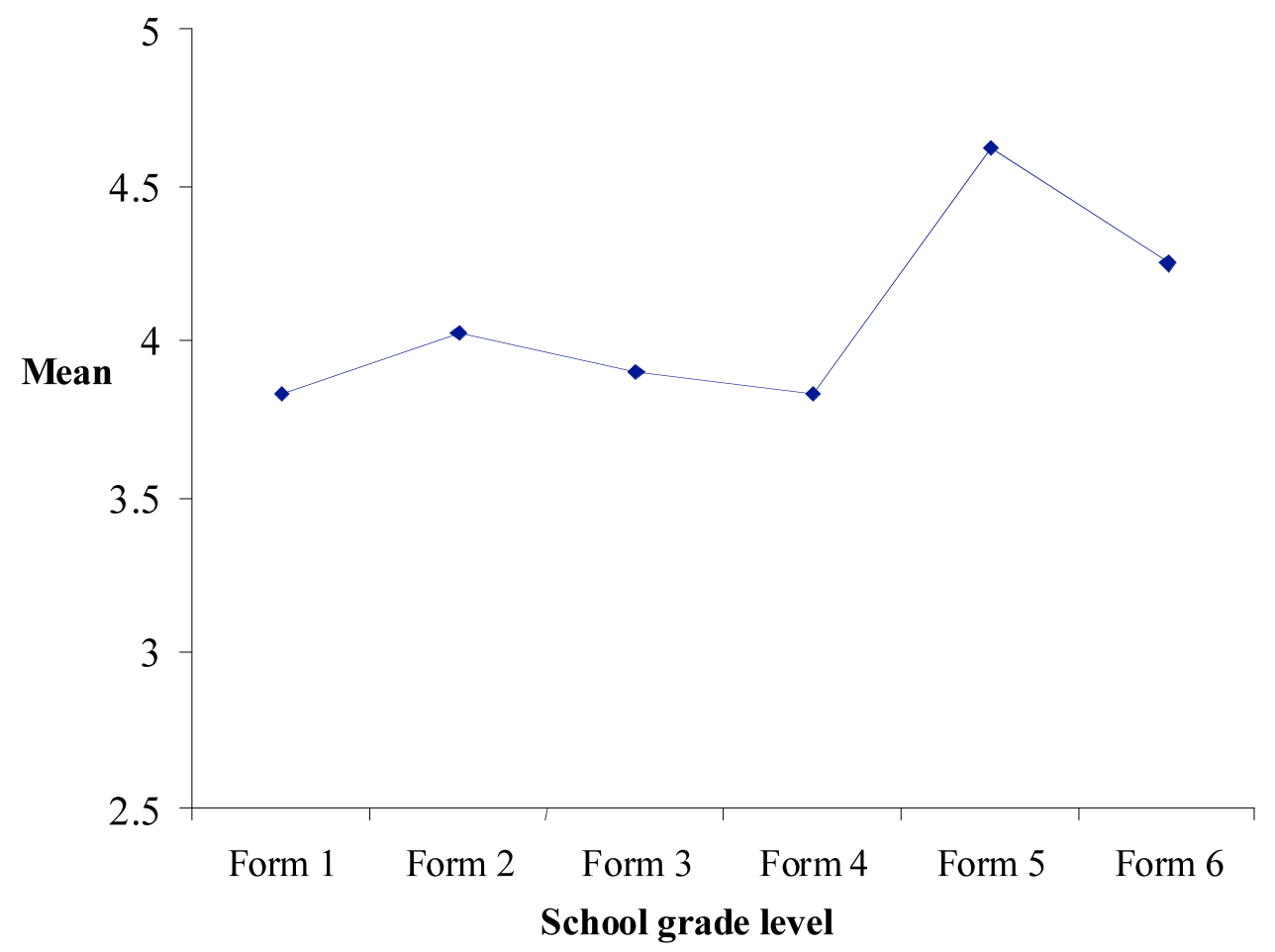

Figure 1. School grade level and NAHK students' motivation

To investigate further, different motivational dimensions (language level, learner level and learning situation level) related to the school form of NAHK students were analysed.

Based on the statistical results, the curve generated in Table 2 reveals no general relationship between the means and school grade level.

Again, at the language level, NAHK students attending Form 5 possess the strongest motivation to learn English, which again indicates HKCE as their primary impetus for learning English and also enhances their extrinsic motivation for same. 
Table 2. School form attending and language level

\begin{tabular}{|c|c|c|c|c|}
\hline \multirow{7}{*}{$\begin{array}{l}\text { Motivation dimen- } \\
\text { sion-Language level }\end{array}$} & School grade level attending & $\mathbf{N}$ & Mean & SD \\
\hline & Form 1 & 19 & 3.824 & 0.940 \\
\hline & Form 2 & 13 & 3.923 & 1.451 \\
\hline & Form 3 & 19 & 3.824 & 0.937 \\
\hline & Form 4 & 32 & 3.739 & 0.885 \\
\hline & Form 5 & 10 & 4.716 & 0.550 \\
\hline & Form 6 & 16 & 4.125 & 1.456 \\
\hline
\end{tabular}

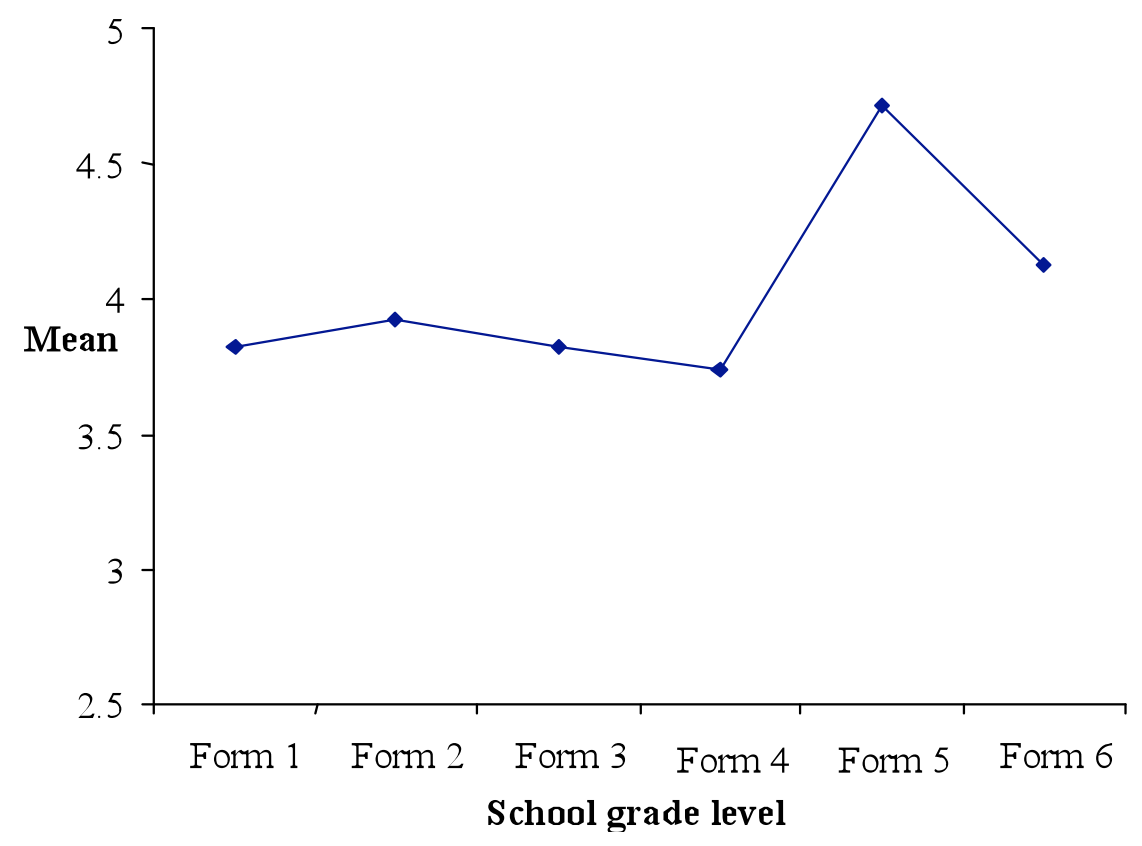

Figure 2. School form attending and NAHK students' motivation at language level.

Results at the learner level generated similar results. No consistent pattern emerges of how school grade level affects NAHK students' motivation to learn English. However, the strongest mean score related to the school grade level attended by NAHK students is again Form 5 (M: 4.719, SD: 0.550), indicating that these Form 5 students have the strongest need to achieve, satisfaction about what they are learning, expectancy of success, and selfconfidence in learning English well. However, this pattern does not tend to change with the school grade level NAHK students are attending. 
Table 3. School form attending and learner level

\begin{tabular}{|c|c|c|c|c|}
\hline & School grade level attending & N & Mean & Std. deviation \\
\cline { 2 - 5 } & Form 1 & 19 & 3.911 & 0.750 \\
\cline { 2 - 5 } & Form 2 & 13 & 4.228 & 1.659 \\
\cline { 2 - 5 } $\begin{array}{l}\text { Motivation dimen- } \\
\text { sion- Learner level }\end{array}$ & Form 3 & 19 & 4.026 & 0.964 \\
\cline { 2 - 5 } & Form 4 & 32 & 3.996 & 0.734 \\
\cline { 2 - 5 } & Form 5 & 10 & 4.719 & 0.418 \\
\cline { 2 - 5 } & Form 6 & 16 & 4.578 & 1.473 \\
\hline
\end{tabular}

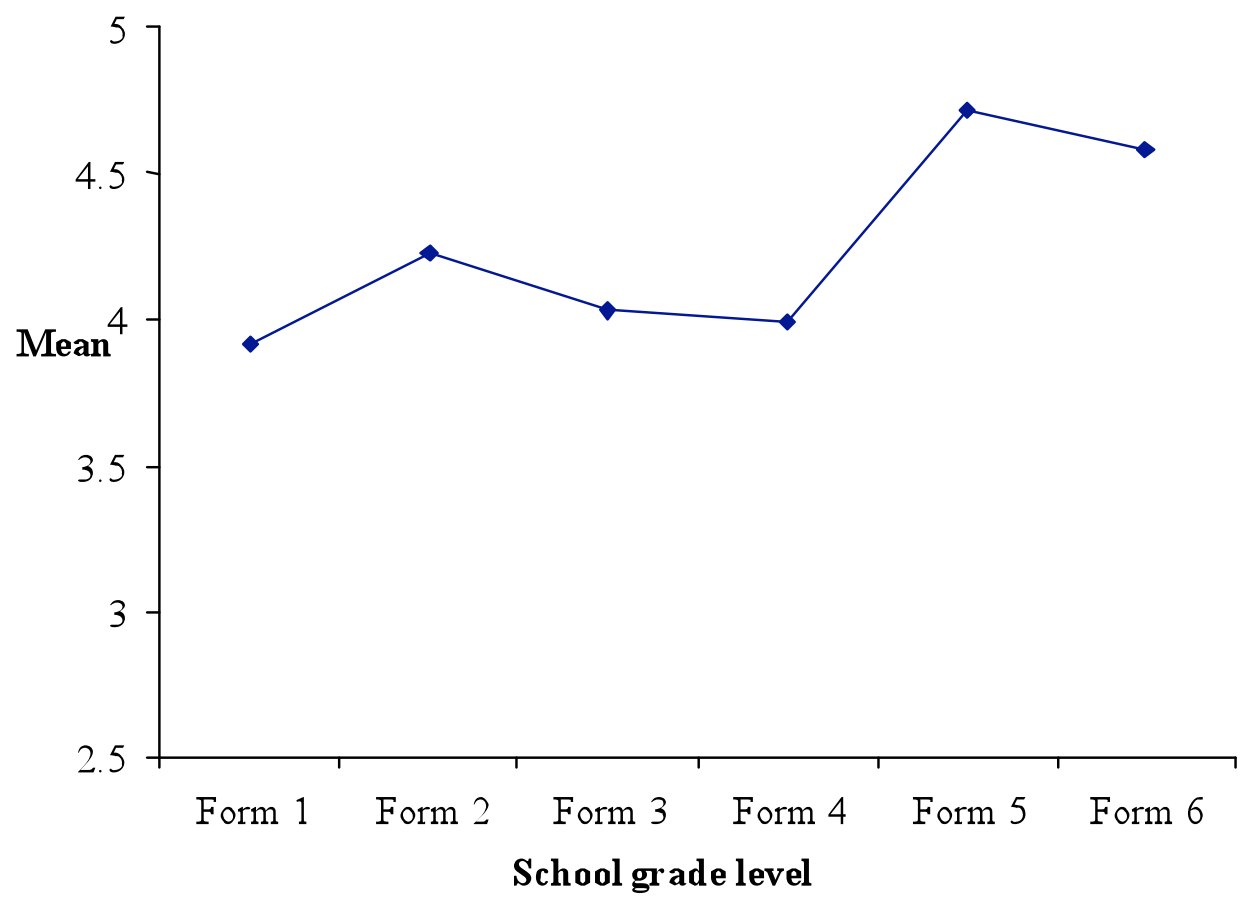

Figure 3. School grade level and NAHK students' motivation at learner level

Even looking at the learning situation level, a level which frequently generates unexpected results, the same statistical result is still predicted. That is, NAHK students attending Form 5 have the strongest motivation to learn at the learning situation level, while other school forms receive different means. 
Table 4. Motivation dimension: Learning situation level

\begin{tabular}{|c|c|c|c|}
\hline School grade level & $\mathrm{n}$ & Mean & Std. deviation \\
\hline Form 1 & 19 & 3.750 & 0.860 \\
\hline Form 2 & 13 & 3.934 & 1.625 \\
\hline Form 3 & 19 & 3.865 & 0.931 \\
\hline Form 4 & 32 & 3.749 & 1.672 \\
\hline Form 5 & 10 & 4.433 & 1.472 \\
\hline Form 6 & 16 & 4.042 & 1.391 \\
\hline
\end{tabular}

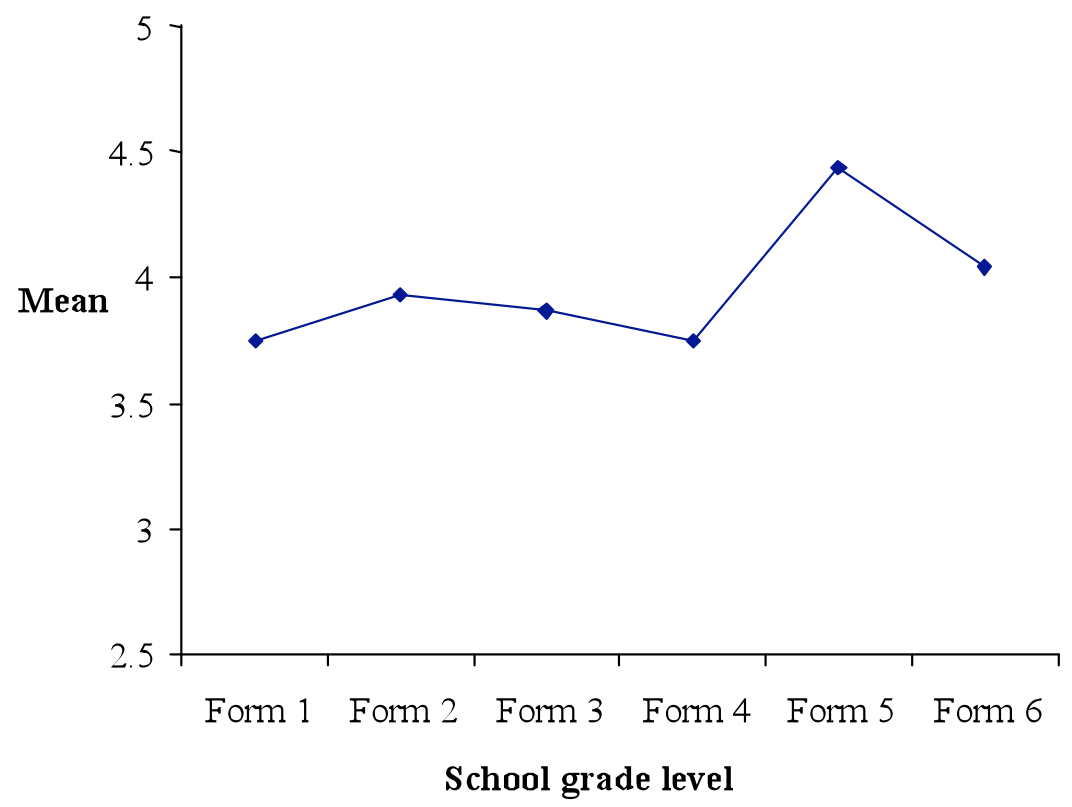

Figure 4. School grade level and NAHK students' motivation at learning situation level

Results generated according to Table 5 are on par with all the above statistical results under different situational related factors. First, there is no general relationship between the means and the grade level. Second, Form 5 received the highest means under all situationalspecific factors. These results indicate that public exam known as The Hong Kong Certificate of Education Examination (HKCEE) is the main source of motivation to learn English for NAHK students, and it simultaneously enhances the influence of other factors on motivation to learn English. 
Table 5. School grade level and specific motivation components

\begin{tabular}{|c|c|c|c|c|}
\hline Motivation components & School grade level & $\mathrm{n}$ & Mean & SD \\
\hline \multirow{6}{*}{$\begin{array}{l}\text { course-specific motivational } \\
\text { components }\end{array}$} & Form 1 & 19 & 3.769 & 1.014 \\
\hline & Form 2 & 13 & 3.794 & 0.902 \\
\hline & Form 3 & 19 & 3.704 & 1.202 \\
\hline & Form 4 & 32 & 3.682 & 0.870 \\
\hline & Form 5 & 10 & 4.150 & 0.717 \\
\hline & Form 6 & 16 & 3.833 & 1.628 \\
\hline \multirow{6}{*}{$\begin{array}{l}\text { teacher-specific motivational } \\
\text { components }\end{array}$} & Form 1 & 19 & 3.872 & 0.917 \\
\hline & Form 2 & 13 & 4.212 & 1.678 \\
\hline & Form 3 & 19 & 4.057 & 1.250 \\
\hline & Form 4 & 32 & 4.011 & 0.712 \\
\hline & Form 5 & 10 & 4.857 & 0.300 \\
\hline & Form 6 & 16 & 4.537 & 0.514 \\
\hline \multirow{6}{*}{$\begin{array}{l}\text { group-specific motivational } \\
\text { components }\end{array}$} & Form 1 & 19 & 3.912 & 1.013 \\
\hline & Form 2 & 13 & 4.141 & 0.758 \\
\hline & Form 3 & 19 & 4.114 & 0.977 \\
\hline & Form 4 & 32 & 3.921 & 0.662 \\
\hline & Form 5 & 10 & 4.683 & 1.359 \\
\hline & Form 6 & 16 & 4.250 & 1.533 \\
\hline \multirow{6}{*}{$\begin{array}{l}\text { parent-specific motivational } \\
\text { components }\end{array}$} & Form 1 & 19 & 3.394 & 0.928 \\
\hline & Form 2 & 13 & 3.521 & 0.893 \\
\hline & Form 3 & 19 & 3.502 & 1.010 \\
\hline & Form 4 & 32 & 3.326 & 0.788 \\
\hline & Form 5 & 10 & 3.961 & 0.854 \\
\hline & Form 6 & 16 & 3.479 & 1.535 \\
\hline \multirow{6}{*}{$\begin{array}{l}\text { culture-specific motivational } \\
\text { components }\end{array}$} & Form 1 & 19 & 3.429 & 0.969 \\
\hline & Form 2 & 13 & 3.616 & 0.738 \\
\hline & Form 3 & 19 & 3.642 & 1.009 \\
\hline & Form 4 & 32 & 3.446 & 1.770 \\
\hline & Form 5 & 10 & 4.107 & 0.776 \\
\hline & Form 6 & 16 & 3.548 & 1.626 \\
\hline
\end{tabular}




\section{Discussions}

This study found no correlation between school grade level and motivation to learn English. However, the unassailable fact is that the public exam is the main motivator for NAHK students to learn English in Hong Kong, as Form 5 is the received the highest means of all levels and situation-related scenarios. Instrumental values and need for achievement were believed to be significant in NAHK students' English learning. NAHK students believe that English skill can help them enter university, secure a good job, and improve their career prospects - which supports findings by Bond (1996).

Although there is no indication that NAHK students possess stronger motivation as they study in higher forms, the results suggest that the approach of the Hong Kong public examination plays a significant role in affecting NAHK students' motivation to learn English in Hong Kong. As higher English skills correlate to higher career prospects (Bond, 1996), English is considered an important subject with strong practical value in the Chinese view. Also, teachers inevitably put more emphasis on public examinations and very often use them as a 'motivator' to encourage students to work harder. In this situation, students will generally experience a much stronger extrinsic motivation than intrinsic motivation, as, again, English is perceived as a highly relevant subject to their studies and career. Because of these expectations from teachers, and the students themselves, students perceive English to have high practical value.

It is well-known that education has a high status in Chinese culture. In Chen's (1998) study, Chinese children perceived education as the central focus of their young lives. Cheng (1999) found that in Hong Kong secondary schools, students in senior forms take competitive examinations to proceed to the next level, whereas those in the junior forms attend school regardless of their abilities and motivation.

\section{Conclusions}

This study established that Hong Kong upper secondary school students overall have stronger motivation, very likely because of their need for further studies and career aspirations. If this is so, it has implications for teaching pedagogy - ESL teachers should be using somewhat differing strategies to motivate different forms of secondary students. If teachers are leading examination classes, teachers can better motivate the NAHK students by simply focussing more on the practical values of learning English, e.g., using themes that are closely related to career prospects. Likewise, when conducting non-examination classes, English teachers can use a more integrated approach, such as using language arts like poems, songs, drama and stories. Therefore, it is recommended that motivation techniques may be included in detail in training courses of teachers and a special training course may be arranged for educational managers, administrators and teachers to use motivation techniques appropriately to help students to learn effectively.

However, English classes in Hong Kong are often challenging in content, and classes typically consist of very different types of students with a broad diversity of motivations. To compensate for these different motivation patterns, teachers of English should adjust their approach to enable students to learn English in the way that is uniquely best-suited 
for them. Teachers are the backbone of education. In order to improve the quality of education, there is a dire need to spend on the teacher training, which in return may provide quality education.

\section{REFERENCES}

Becker, M.V. et al. (2012). "Culture and the distinctiveness motive: Constructing identity in individualistic and collectivistic contexts", in Journal of Personality and Social Psychology, 102, 4: 833-55.

Bond, M. H. (ed.) (1996). The Handbook of Chinese Psychology. Hong Kong: New York: Oxford University Press.

Brooks, A. A. R. (1997). Learning Strategies as Learning Inhibitors for Chinese Speakers. Paper presented at the Annual Meeting of the Teachers of English to Speakers of Other Languages (31st, Orlando, FL, March 11-15, 1997).

Brooks, N., Bruno, E. \& Burns, T. (1997). Reinforcing students' motivation through parent interaction. Master's thesis, Saint Xavier University IRI/Skylight, 1997. ERIC (ED411074).

Brophy, J. (1987). "Synthesis of Research on Strategies for Motivating Students to Learn", in Educational Leadership, October 1987: 40-8.

Chen, X. M. (1998). 'Sojourners and 'Foreigner: A Study on Chinese Students' Intercultural Interpersonal Relationships in the United States". Changsha: Humana Jiao Yu Chu Ban She.

Cheng, S. T. (1999). "Perception of classroom environment in Hong Kong: Differences between students in junior and senior forms", in Adolescence, 34, 136: 793-8.

Cheung, C. S. S. \& Pomerantz, E. M. (2012). "Why does parents' involvement enhance children's achievement? The role of parent-oriented motivation", in Journal of Educational Psychology, 104, 3: 820-32.

Chiu, M. M. \& Chow, B W. Y. (2010). "Culture, Motivation, and Reading Achievement: High School Students in 41 Countries", in Learning and Individual Differences, 20, 6: 579-92.

Clement , R. \& Noels, K. A. (1992). "Towards a situated approach to ethnolinguistic identity: The effects of status on individuals and groups", in Journal of Language and Social Psychology, 11: 203-32.

Corpus, J. H. \& Lepper, M. R. (2007). "The effects of person versus performance praise on children's motivation: Gender and age as moderating factors", in Educational Psychology, 27, 4: 487-508.

Deci, E. L. \& Ryan, R. M. (1985) Intrinsic Motivation and Self-Determination in Human Behaviour. New York: Plenum Press.

Dörnyei, Z. \& Schmidt, R. (2001) Motivation and Second Language Acquisition. Honolulu: University of Hawaii Press.

Dörnyei, Z. (1998). "Motivation in second and foreign language learning", in Language Teaching, 31: $117-35$.

Eccles, J. \& Wigfield, A. (1995). "In the Mind of the Actor: The structure of adolescents' achievement task values and expectancy-related beliefs", in Personality and Social Psychology Bulletin, 21, 3: 215-25.

Eccles, J. S. \& Harold, R. D. (1993). "Parent-school involvement during the early adolescent years", in Teachers College Record, 94: 568-87.

Folmer, A. S., Cole, D. A., Sigal, A. B., Benbow, L. D. Satterwhite, L.F. Swygert, K.E. \& Cisela, J. A. (2008). "Age-related changes in children's understanding of effort and ability: Im- 
plications for attribution theory and motivation", in Journal of Experimental Psychology, 99, 2: 114-34.

Froiland, J. (2011). "Parental Autonomy Support and Student Learning Goals: A Preliminary Examination of an Intrinsic Motivation Intervention", in Child \& Youth Care Forum. 40, 2: $135-49$.

Ghazi, S. R., Ali, R., Shahzad, S. \& Khan, M. S. (2010). "Parental Involvement in Children Academic Motivation", in Asian Social Science, 6, 4: 93-9.

Giles, H. \& Byrne, J. L. (1982). "An intergroup approach to second language acquisition", in Journal of Multilingual and Multicultural Development, 3: 17-40.

Grolnick, W. S. \& Slowiaczek, M. L. (1994). "Parents' involvement in children's schooling: A multidimensional conceptualisation and motivational model", in Child Development, 65: 237-52.

Gutman, L. M. \& Midgley, C. (2000). "The role of protective factors in supporting the academic achievement of poor African American students during the middle school transition", in Journal of Youth and Adolescence, 29, 2: 223-48.

Henderson, A. \& Berla, N. (1994). A New Generation for Evidence: The family is critical to student achievement. Washington, DC: The Centre for Law and Education.

Huang, G. H. C. \& Mason, K. L. (2008). "Motivations of Parental Involvement in Children's Learning: Voices from Urban African American Families of Preschoolers", in Multicultural Education, 15, 3: 20-7.

Ma, X. (1999). "Dropping out of advanced Mathematics: The effect of parental; involvement", in Teacher College Record, 101, 1: 60-81.

Maehr, M. L. (2008). "Culture and achievement motivation", in International Journal of Psychology, 43, 5: 917.

Mordkowitz, E. R. \& Ginsburg, H. P. (1987). "Early academic socialisation of successful AsianAmerican college students", in The Quarterly Newsletter of the Laboratory of Comparative Human Cognition, 9, 2: 85-91.

Niles, F. S. (1995). "Cultural differences in learning motivation and learning strategies: A comparison of overseas and Australian students at an Australian university", in International Journal of Intercultural Relations, 19, 3: 369-85.

Oxford, R. L. \& Shearin, J. (1994). "Language learning motivation: expanding the theoretical framework", in Modern Language Journal, 78: 12-28.

Shumow, L. \& Miller, J. D. (2001). "Parents' at-home and at-school academic involvement with young adolescence", in Journal of Adolescent Research, 14, 3: 359-82.

Stephens, J. M., Romakin, V., Yukhymenko, M. (2010). "Academic motivation and misconduct in two cultures: A comparative analysis of US and Ukrainian undergraduates", in International Journal for Educational Integrity, 6, 1: 47-60.

Stevenson, H. W. \& Stigler, J. (1992). The learning gap: Why our schools are failing and what can we learn from Japanese and Chinese education. New York: Summit Books.

Szeto, A., Sorrentino, R.,Yasunaga, S., Kouhara, S. \& Lin, L. (2011). "Motivation and performance: Uncertainty regulation in Canada and Japan", in Motivation and Emotion, 35, 3: $338-50$.

Thijs, J. (2011). "Ethnic Differences in Teacher-Oriented Achievement Motivation: A Study Among Early Adolescent Students in the Netherlands", in Journal of Genetic Psychology. 172, 2: 121-40.

Trumbull, E. \& Rothstein-Fisch, C. (2011). "The Intersection of Culture and Achievement Motivation", in School Community Journal, 21, 2: 25-53. 
Williams, M. \& Burden, R. (1997). Psychology for Language Teachers. Cambridge: Cambridge University Press.

Wlodkoswki, R. J. \& Jaynes, J. H. (1990). Eager to Learn. San Francisco: Jossey Bass.

Wong, R. M. H. (2007a). Factors Affecting Motivation to Learn English: The perspective of newly arrived Hong Kong students. Unpublished doctoral thesis. University of Durham.

Wong, R. M. H. (2007b). "Motivation and English Attainment: A comparative study of HK students with different cultural backgrounds", in Asia Pacific Education Researcher, 17, 1: 45-60. 